\title{
PENGALAMAN PERAWAT JIWA MELAKUKAN SELF MANAJEMEN DIRI DALAM MENGELOLA STRES DIMASA PANDEMI COVID-19
}

\author{
Maradona, Yati Afiyanti, Muhammad Syafwani \\ ${ }^{1 \& 3}$ Universitas Muhammadiyah Banjarmasin, ${ }^{2}$ Universitas Indonesia (UI) Depok Jawa \\ Barat, Indonesia \\ Email: maradona198801@gmail.com, yatiafiyanti@yahoo.com, \\ m.syafwanibjm@gmail.com
}

\begin{abstract}
Abstrak
Munculnya Virus COVID-19 telah menarik perhatian global, dan Pada 30 Januari WHO telah menyatakan COVID-19 sebagai darurat kesehatan masyarakat yang menjadi perhatian internasional. Penyakit yang disebabkan oleh sindrom pernapasan akut parah coronavirus telah dilaporkan di seluruh dunia lebih dari 2 juta kasus, termasuk lebih dari 120.000 kematian. Sedangkan di Indonesia menurut data Kemenkes RI Tahun 2020 sampai dengan tanggal 25 Maret 2020, dilaporkan total kasus konfirmasi 414.179 dengan 18.440 kematian 4,4\% dimana kasus dilaporkan di 192 negara/wilayah. Stres kerja pada masa pandemi ini juga dialami oleh perawat Jiwa yang muncul dari adanya beban kerja yang berlebih dan Kondisi pasien yang memungkinkan bisa menyerang petugas dan sering sekali Alat pelindung diri Perawat terlepas sehingga hal tersebut berpengaruh pada diri perawat dalam hal psikologis perawat. Penelitian ini bertujuan untuk mengekplorasi Pengalaman Perawat Jiwa Melakukan Self manajemen Diri Dalam Mengelola Stres Dimasa Pandemi COVID-19. Data kualitatif diperoleh melalui indepth interview pada 16 orang partisipan Rumah Sakit Jiwa Kalawa Atei dengan mengunakan metode kualitatif dengan teknik purposive sampling. Hasil penelitian menemukan 6 tema utama yaitu (1) Prilaku pasien ODGJ saat di rawat, (2) Respon fisik perawat saat merawat pasien ODGJ dengan COVID-19, (3) Respon psikologis saat merawat ODGJ dengan COVID-19, (4) Tingkat stres saat merawat ODGJ dengan COVID19, (5) Cara mengelola Stres saat merawat pasien ODGJ dengan COVID-19, (6) Keberhasilan mengelola diri mengatasi stress saat merawat pasien ODGJ dengan COVID-19. Simpulan dari penelitian ini bahwa perawat perlu suatu adaptasi dalam mengelola stress dengan melakukan manajemen diri dalam mengelola stress ketika memberikan asuhan kepada pasien.
\end{abstract}

Kata Kunci: COVID-19; ODGJ; Self manajemen diri perawat.

\section{Abstract}

The emergence of the COVID-19 Virus has attracted global attention, and On January $30 \mathrm{WHO}$ has declared COVID-19 a public health emergency of international concern. The disease caused by the severe acute respiratory syndrome coronavirus has been reported worldwide more than 2 million cases, including more than 120,000 deaths. Meanwhile in Indonesia, according to data from the Ministry of Health of the Republic of Indonesia in 2020 until March 25,

$\begin{array}{ll}\text { How to cite: } & \begin{array}{l}\text { Maradona, Afiyanti,Y., Syafwani, M., (2022) Pengalaman Perawat Jiwa Melakukan Self Manajemen Diri } \\ \text { dalam Mengelola Stres Dimasa Pandemi Covid-19, Syntax Idea, 4(1), https://doi.org/10.36418/syntax- } \\ \text { idea.v4i1.1718 }\end{array} \\ \begin{array}{ll}\text { E-ISSN: } & 2684-883 X \\ \text { Published by: } & \text { Ridwan Institute }\end{array}\end{array}$


2020, a total of 414,179 confirmed cases were reported with 18,440 deaths, $4.4 \%$ of which cases were reported in 192 countries/regions. Work stress during this pandemic is also experienced by mental nurses who arise from excessive workloads and patient conditions that allow them to attack officers and often the nurse's personal protective equipment is detached so that this affects nurses in terms of nurses' psychology. This study aims to to explore the experience of mental nurses doing self-management in managing stress during the COVID-19 pandemic. Qualitative data were obtained through in-depth interviews with 16 participants at the Kalawa Atei Mental Hospital using a qualitative method with purposive sampling technique. The results of the study found 6 main themes, namely (1) Behavior of ODGJ patients while being treated, (2) The physical response of nurses when treating ODGJ patients with COVID-19, (3) Psychological responses when treating ODGJ with COVID-19, (4) Stress levels when treating ODGJ with COVID-19, (5) How to manage stress when treating ODGJ patients with COVID19, (6) Successfully managing yourself in overcoming stress when treating ODGJ patients with COVID-19. The conclusion from this study is that nurses need an adaptation in managing stress by self-management in managing stress when providing care to patients.

Keywords: COVID-19; ODGJ; Nurse self manajement

\section{Received: 2021-12-22; Accepted: 2022-01-05; Published: 2022-01-20}

\section{Pendahuluan}

Munculnya Virus COVID-19 telah menarik perhatian global, dan Pada 30 Januari WHO telah menyatakan COVID-19 sebagai darurat kesehatan masyarakat yang menjadi perhatian internasional (Dong et al., 2020). Penyakit yang disebabkan oleh sindrom pernapasan akut parah coronavirus 2 (SARS-CoV-2), telah dilaporkan di seluruh dunia (Sharma, Tiwari, Deb, \& Marty, 2020). Lebih dari 2 juta kasus, termasuk lebih dari 120.000 kematian, telah dilaporkan di Amerika Serikat (AS) (CDC, 2020). Sedangkan di Indonesia menurut data Kemenkes RI Tahun 2020 sampai dengan tanggal 25 Maret 2020, dilaporkan total kasus konfirmasi 414.179 dengan 18.440 kematian (CFR 4,4\%) dimana kasus dilaporkan di 192 negara/wilayah.

Untuk di Kalimantan Tengah berdasarkan data dari satgas COVID-19Palangka Raya tanggal 9 Juni 2021, telah dilaporkan 2.3315 orang terkonfirmasi positif COVID19 dan ada 625 kematian (CFR: 2,7\%) terkait COVID-19 yang dilaporkan dan 2.1461 pasien telah sembuh dari penyakit tersebut. Untuk di Kota Palangkaraya berdasarkan data dinas Kesehatan Provinsi Kalimantan Tengah hingga 9 Juni 2021 dilaporkan 6626 orang terkonfirmasi positif COVID-19dan ada 206 kematian terkait COVID-19 yang dilaporkan dan 6094 pasien telah dinyatakan sembuh.

Selama epidemi SARS China, hampir 50\% orang yang terinfeksi adalah petugas kesehatan (McAlonan et al., 2007). Dalam hal ini, perawat klinis, sebagai kelompok berisiko tinggi dengan kontak langsung dengan pasien yang didiagnosis atau dicurigai mengidap COVID-19, mungkin menghadapi pekerjaan yang hebat dan tekanan 
psikologis. Bagaimana melindungi status psikologis para pelindung tersebut telah menjadi area perhatian penting selama wabah COVID-19.

Sebuah studi yang dilakukan oleh (Yuan et al., 2020) Tentang Perbandingan indikator stres psikologis penduduk provinsi Hubei dan provinsi non endemis di China selama dua minggu pada saat wabah penyakit coronavirus 2019 (COVID-19) pada Februari 2020 ". Menyatakan "bahwa terdapat 622 partisipan penelitian dengan kondisi emosi, 497 dengan respon somatik, 527 dengan kualitas tidur yang menurun, dan 471 dengan perubahan perilaku.

Stres mengacu pada respons non-spesifik individu yang disebabkan oleh stres, termasuk respons fisiologis dan respons psikologis (Kruk, Aboul-Enein, Bernstein, \& Gronostaj, 2019). Penelitian telah menunjukkan bahwa sekitar 75\% -90\% penyakit terkait dengan aktivasi stres (Kruk et al., 2019), (Hales, Carroll, Fryar, \& Ogden, 2017), (Yaribeygi, Panahi, Sahraei, Johnston, \& Sahebkar, 2017). Secara khusus, stres berkaitan erat dengan kerusakan fungsi otak termasuk gangguan memori, kognisi dan pembelajaran (Frith \& Frith, 2001) dan berhubungan dengan komplikasi gastrointestinal dengan mempengaruhi nafsu makan dan fungsi normal saluran cerna (Yaribeygi et al., 2017).

Tingkat stres perawat klinis secara langsung mempengaruhi kesehatan fisik dan mental serta efisiensi kerja mereka. Oleh karena itu, perlu diketahui tingkat stres perawat klinis pada periode khusus ini. Efikasi diri adalah konstruksi psikologis yang menonjol yang terkait dengan stres, yaitu spekulasi dan penilaian individu tentang apakah mereka mampu melakukan perilaku tertentu (Vickers, 2017).

Stres kerja pada masa pandemi ini juga dialami oleh perawat Jiwa yang muncul dari adanya beban kerja yang berlebih dan Kondisi pasien yang memungkinkan bisa menyerang petugas dan sering sekali APD Perawat terlepas sehingga hal tersebut berpengaruh pada diri perawat dalam hal emosional. Terlebih lagi tingkat stres juga dikarenakan melihat pasien COVID-19 yang sudah diberikan asuhan keperawatan secara maksimal berujung pada kematian atau perilaku menyerang dan agresif. Kekhawatiran dari dalam diri perawat juga muncul karena tertular COVID-19 karena rumah sakit adalah tempat yang rawan penularan pandemi COVID-19 pada saat ini. Tingkat stres yang dialami oleh perawat jiwa disebabkan oleh tiga faktor yang mempengaruhi seperti karakteristik, lingkungan kerja dan manajemen Ruangan yang jelek.

Menurut (Sockalingam, Clarkin, Serhal, Pereira, \& Crawford, 2020) Beberapa saran untuk manajemen stres mungkin bisa membantu: menjaga jadwal dan diet yang sehat; berolahraga atau melakukan sesuatu yang membuat Anda bahagia; istirahat di tempat kerja; pantau emosi Anda; cobalah bernapas dalam-dalam atau mendengarkan musik untuk bersantai; dan mencari bantuan dari psikolog profesional bila diperlukan untuk mengatasi Stres.

Secara khusus rumah sakit jiwa mempunyai keunikan dalam memberikan pelayanan perawatan pada pasien ODGJ dimana pasien yang mengalami gangguan fungsi mental mengalami masalah pada kemampuan kognitif yang tidak adekuat 
mengakibatkan pasien menjadi susah mengenali faktor resiko yang ada, sulit diarahkan dalam melakukan perlindungan terhadap dirinya seperti pasien yang tidak patuh mengikuti anjuran untuk menggunakan masker serta prosedur cuci tangan yang baik. Hal ini merupakan sebuah tantangan dan menjadi pengalaman baru dalam memberikan asuhan keperawatan dan pelaksanaan prosedur tindakan kepada pasien ODGJ dengan COVID-19 yang sebelumnya belum pernah terjadi. bahkan standar prosedur operasionalnya dibuat dengan menyesuaikan kondisi yang terdapat pada unit pelayanan pasien.

Perawat Jiwa sangatlah erat hubunganya dengan klien dengan gangguan jiwa baik berupa Halusinasi Pendengaran, Harga diri rendah dan isolasi social dengan kondisi masih relative tenang dan koperatif atau bahkan klien yang gelisah dan tidak koperatif dan di Rumah sakit jiwa juga sering perawat jiwa berhadapan langsung dengan perilaku agresif atau tindak kekerasan yang dilakukan oleh klien baik secara verbal maupun non verbal (kekerasan fisik), terutama perawat yang bekerja di ruang akut (RDP) atau intensif Jiwa dimana perawat berada dalam lingkungan yang terbatas dan memungkinkan perawat berada dekat dengan klien untuk mengobservasi kondisi klien dan mengevaluasi tindakan perawatan maupun tindakan medis yang dilakukan dan pada saat pandemi covid terjadi dalam hal perawatan klien dengan perilaku agresif yang terkonfirmasi COVID-19 sangat harus berhati- hati karena besar kemungkinan APD akan terlepas dan sangat berbahaya untuk perawat jiwa yang memberikan tindakan.

Adapun (Stuart, G. W., \& Laraia, 2008) juga mengatakan bahwa perawat jiwa atau psikiatri bekerja merawat klien dengan ketidakadekuatan mekanisme koping terhadap stres. Klien yang masuk di ruang darurat psikiatri pada umumnya berada dalam situasi krisis demikian juga mekanisme pertahanan diri mereka yang kurang efektif, sehingga selama periode ini tindakan penyerangan atau kekerasan dapat terjadi.

Berdasarkan penelitian yang dilakukan oleh (Elita, 2011) di RSJ Provinsi Riau, didapatkan hasil yang mengambarkan bahwa klien yang melakukan kekerasan fisik sebesar 84\%, kekerasan berupa ancaman verbal $80 \%$ ini merupakan kekerasan fisik yang dilakukan oleh pasien dengan gangguan jiwa kepada perawat yang memberikan tindakan keperawatan, dan juga perawat yang mengalami kekerasan fisik oleh klien sebesar $20 \%$.

Berdasarkan penelitian yang dilakukan oleh (Husada, 2015) di RSJ Daerah, ditemukan klien yang melakukan kekerasan fisik dan non fisik sebesar 36\% dengan kategori sering dan perawat yang mengalami stres ringan sebesar $43 \%$ dengan hasil penelitian didapatkan nilai $\rho$ value $0,01<0,05$ yang berarti ada hubungan signifikan antara perilaku kekerasan yang di lakukan klien dengan gangguan jiwa dengan stres perawat.

Kesiapan baik fisik maupun psikologis dan manajemen stress mutlak diperlukan perawat dalam menjalankan tugasnya. Seringkali perawat jiwa untuk menghadapi situasi yang tidak menyenangkan (risk situation) di tempat kerja dengan perilaku pasien yang mampu membuat perawat kehilangan konsentrasi. Perilaku kekerasan yang dilakukan pasien dapat berakibat fatal baik bagi perawat maupun pasien tersebut. Bila 
situasi ini tidak segara di atasi, tidak menutup kemungkinan akan menimbulkan stress dan konflik pada diri perawat jiwa.

Upaya yang bisa dilakukan untuk mengurangi tekanan pada tenaga kesehatan Krisis psikologis pada Perawat Jiwa yang diakibatkan pandemi COVID-19 diperkirakan akan memicu kebutuhan mendesak untuk merancang dan mengimplementasikan dukungan psikososial dan intervensi program untuk mengurangi tekanan psikologis. Pada saat terjadi krisis kesehatan dan perubahan tekanan kerja yang hebat, program trauma healing, hypnoterapi, dan pendampingan ahli kejiwaan yang secara rutin melakukan penyegaran psikologis bagi para tenaga kesehatan, sebaiknya menjadi pertimbangan strategi selain strategi kuratif yang berfokus pada kesembuhan fisik pasien (Economou et al., 2016).

Strategi koping untuk mengatasi stres yang dipilih oleh perawat merupakan suatu fenomena yang unik yang dialami oleh perawat jiwa. Keunikan dari fenomena ini adalah proses yang dialami perawat adalah suatu pengalaman yang natural ketika menghadapi stres, menanggapi stresor yang dihadapi, bagaimana mereka memilih cara dan strategi terbaik yang dapat diperbuat untuk menyelesaikan stres.

Berdasarkan uraian tersebut penelitian ini akan mengeksplorasi Pengalaman Perawat Jiwa melakukan Self Manajemen Diri dalam Mengelola Stres dimasa pandemi COVID-19.

\section{Metode Penelitian}

Penelitian ini menggunakan metode penelitian kualitatif dengan pendekatan fenomenologi, yang bertujuan untuk mengidentifikasi dan Mengeksplorasi pengalaman perawat Jiwa dalam melaksanakan self manajemen diri dalam mengelola stres di masa pandemi COVID-19. Ada enam belas responden yang terlibat pada penelitian ini. Enam belas responden ini adalah seluruh perawat jiwa yang berkerja di ruang perawatan COVID-19.

\section{Hasil dan Pembahasan}

Partisipan dalam penelitian ini adalah anggota perawat yang pernah merawat pasien dengan diagnosa COVID-19. Sebanyak 16 (enam belas) orang perawat berpartisipasi dalam penelitian ini. Partisipan laki-laki sebanyak 12 orang dan partisipan perempuan 4 orang. Usia partisipan bervariasi dengan usia termuda 26 tahun dan tertua 40 tahun. Status pekerjaan partisipan 10 orang PNS dan 6 orang tenaga kontrak. Latar belakang pendidikan partisipan yaitu pendidikan Ners sebanyak 8 orang dan pendidikan Diploma 8 orang

Hasil penelitian mengidentifikasi pengalaman perawat Jiwa dalam melaksanakan self manajemen diri dalam mengelola stres di masa pandemi COVID-19 sebanyak 6 tema sebagai berikut:

1. Perilaku pasien ODGJ saat di rawat

Secara khusus rumah sakit jiwa mempunyai keunikan yaitu dalam memberikan pelayanan perawatan pada pasien ODGJ dimana pasien yang mengalami gangguan 
fungsi mental dalam hal prilaku agresif dan juga mengalami masalah pada kemampuan kognitif yang tidak adekuat mengakibatkan pasien menjadi susah mengenali faktor resiko yang ada, sulit diarahkan dalam melakukan perlindungan terhadap dirinya seperti pasien yang tidak patuh mengikuti anjuran yang di perintahkan oleh perawat dalam proses perawatan di Rumah Sakit. Presepsi perawat tentang Perilaku pasien ODGJ yaitu suatu bentuk pengamatan yang dilakukan oleh seorang perawat dalam merawat pasien ODGJ baik perilaku yang bertujuan untuk melukai perawat secara fisik maupun psikologis dengan mengancam perawat.

Senada dengan yang diungkapkan (Keliat, 2011), (Damaiyanti dan Iskandar, 2014), (Prabowo, 2014) bahwa perilaku kekerasan dapat berbentuk secara verbal juga dalam bentuk aksi fisik seperti mengamuk. Dalam bentuk verbal berupa aksi yang agresif diungkapkan dalam bentuk kata-kata yang kotor, umpatan, serta ejekan dan berbicara dengan nada keras, serta ancaman melalui kata-kata yang menyakiti perasaan lawan bicara. emosi yang timbul sebagai reaksi terhadap kecemasan yang meningkat dan dirasakan sebagai ancaman, perasaan terhadap keadaan yang tidak menyenangkan seperti kecewa, tidak puas, tidak tercapai keinginan. bentuk aksi fisik juga ditunjukkan dengan tindakan memukul, mengancam orang lain dengan senjata, menendang, menyerang orang lain dan merusak barang orang lain.

Senada dengan yang diungkapkan (Keliat, 2011), (Damaiyanti dan Iskandar, 2014), (Prabowo, 2014) bahwa perilaku kekerasan dapat berbentuk secara verbal juga dalam bentuk aksi fisik seperti mengamuk. Dalam bentuk verbal berupa aksi yang agresif diungkapkan dalam bentuk kata-kata yang kotor, umpatan, serta ejekan dan berbicara dengan nada keras, serta ancaman melalui kata-kata yang menyakiti perasaan lawan bicara. emosi yang timbul sebagai reaksi terhadap kecemasan yang meningkat dan dirasakan sebagai ancaman, perasaan terhadap keadaan yang tidak menyenangkan seperti kecewa, tidak puas, tidak tercapai keinginan. bentuk aksi fisik juga ditunjukkan dengan tindakan memukul, mengancam orang lain dengan senjata, menendang, menyerang orang lain dan merusak barang orang lain. Beberapa partisipan pada penelitian ini mengatakan

“..Saat kita melakukan tindakan dengan pasien yang gelisah Itu kita selalu penuh dengan kehati-hatian Baik dalam kita memberikan tindakan atau memberikan terapi"

“..misalkan kalaunya dia gelisah kita harus memerlukan banyak orang untuk menangani pasien gelisah itu

“...pertama resiko kabur karna saat kita buka kamarnya kan gelisah kemungkinan dia akan kabur "

Perbedaan lainya yang di rasakan oleh partisipan adalah adanya perbedaan antara pasien Koperatif dengan pasien tidak koperatif pada pasien OGDJ dengan COVID-19 dengan ungkapan partisipan

"...Perbedaannya ya lebih khawatir sama yang gelisah sih terus kalau misalkan dia tenang kemungkinan untuk kita merawat seorang diri masih bisa kan” 
“...Kalau untuk yang kooperatif itu kita bisa menanganinya sendiri atau berdua, berdampingan sama teman sejawat untuk menangani pasien tersebut”

“...Kalo pasien Komperatif itu santai aja sih ee rileks seperti biasa saja sih kita merawat pasien biasa kan jadi komperatif tenang tinggal kita kasih instruksi atau mereka ngikutin aja sama seperti pasien biasa."

"...Kalo pasien Komperatif itu santai aja enak aja di rawatnya mudah di atur dan di arahkan bahkan untuk ADL pun mereka mandiri bahkan di suruh senam pun mau”

“...pasien Komperatif itu santai aja enak aja di rawatnya dan nurut.."

Di kaitkan dengan penelitin di atas dan dihubungkan dengan teori Adaptasi Roy bahwa Presepsi perawat tentang perilaku pasien ODGJ saat di rawat merupakan sebuah tantangan yang menuntut adaptasi secara fisik dan psikis perawat. Perilaku tidak terkontrol dari pasien dapat membahayakan dirinya maupun perawat, hal ini menjadi stimulus pada system control kognator dan regulator yang mempelajari kondisi pasien dan cara aman yang bisa dilakukan untuk menolong pasien.

2. Respon fisik perawat saat merawat pasien ODGJ dengan COVID-19

Psikosomatik yang sekarang lebih dikenal sebagai penyakit Psikofisiologis merupakan penyakit fisik yang gejalanya disebabkan oleh proses mental dari penderitanya Psikosomatis dapat timbul dalam beberapa keluhan umum, misalnya keluhan nyeri, sakit di dada atau rasa sesak napas respon batuk, merasa panas dan demam. Keluhan seperti ini tentu saja tidak akan membaik bila diatasi dengan obat sakit perut atau sesak napas. Jika dilakukan pemeriksaan juga tidak akan ditemukan adanya keluahan nyeri gangguan pada dadanya dan juga respon psikosomatik pada Pengalaman perawat dalam bertugas merawat pasien ODGJ dengan COVID-19 yang mengharuskan perawat bekerja menggunakan APD yang lengkap dengan tujuan pencegahan penularan infeksi COVID-19 dari pasien seperti merasa panas, susah bernafas dan terganggu penglihatan.

Menurut (Febriana, 2016) gejala psikosomatis ditandai dengan adanya keluhan fisik yang beragam, antara lain: pegal, nyeri otot, demam batuk, mual muntah dan nafas sesak, respon demam gangguan fisik ini yang disebabkan oleh tekanan-tekanan emosional dan psikologis atau gangguan fisik yang terjadi sebagai akibat dari kegiatan psikologis yang berlebihan dalam mereaksi gejala emosi Ini sesuai dengan hasil penelitian ini dimana beberapa partisipan mengatakan demam beberapa hari setelah merawat pasien ODGJ dengan COVID-19 dan juga muncul perasaan gatal pada tenggorokan dan diperkuat oleh peneliti Dalam penelitian (Zeng, Sun, Yang, Shen, \& Liu, 2016) yang berjudul The Ttheoretical Construction of a Classification of Clinical Somatic Symptoms in Psychosomatic Medicine Theory. Hasil penelitian ini menunjukkan bahwa terdapat model teoritis yang terdiri dari empat dimensi yaitu gejala somatik emosional, gejala somatik biologis, gejala somatik imajinatif dan gejala somatik kognitif. Ini sesuai dengan hasil penelitian ini dimana beberapa partisipan mengatakan demam kadang- kadang- mucul kadang juga hilang sendiri dan juga muncul perasaan batuk. 
“...respon fisik saya pernah juga merasakan batuk batuk saya takut sekali saya kira kena covid pedahal tidak aja"

“...ada juga saya merasakan batuk terus menerus setelah merawat pasien covid "

“...respon fisik yang saya alami, pak terus terang sekarang berbeda beda pak

kita awalnya mungkin pikiran atau stress ya, mislanya gejala covid demam batuk pilek..."

Penggunaan APD level 3 menimbulkan pengalaman tidak nyaman atau menimbulkan gejala psikosomatik terlebih saat awal dalam menggunakannya. Seperti dalam penelitian (Yuan et al., 2020) mengatakan diantara 129 profesional perawat kesehatan yang diteliti, sebanyak 122(94,57\%) tenaga kesehatan mengalami ketidaknyamanan saat memakai APD level 3 untuk merawat pasien COVID-19. Alasan utamanya adalah terjadinya berbagai tingkat reaksi kulit yang merugikan, kesulitan bernapas, stres karena panas, pusing dan mual terganggu penglihatan. Perasaan panas yang dirasakan karena coverall yang digunakan terbuat dari bahan poliethylene (plastik) yang sifatnya kedap air dan tahan terhadap bahan kimia. Ini sesuai dengan hasil penelitian ini dimana beberapa partisipan mengatakan

“...Mengunakan APD Panas ee pengap, susah nafas juga”. "Ee maskernya kan double-double tuh"..

"...Kalau yang saya rasakan itu yang pertama pengap susah bernafas"

"...Kalau yang saya rasakan itu yang pertama pengap susah bernafas Karena masker yang kita gunakan itu KN-95 dan bukan N-95"

"...sesak nafas itu sudah pasti karena lama mengunakan APD dan masker"

"...sesak nafas itu sudah pasti karena lama mengunakan APD dan masker berlapis lapis itu yang membuat sesak”

Beberapa partisipan pada penelitian ini juga mengatakan respon psikosomatik yang mereka rasakan dapat muncul dalam beberapa hari setelah merawat pasien ODGJ dengan COVID-19 namun setelah dilakukan pemeriksaan semua hasil pemeriksaan normal dengan ungkapan partisipan

“...yang saya rasakan ada rasa seperti demam setelah beberapa hari merawat pasien COVID-19"

“...kadang muncul perasaan demam namun setelah di cek normal aja tidak ada masalah"

"...Untuk yang pertama kali merawat mungkin ada kayak simtom untuk jadi gitu kayak merasa eee menggigil seperti demam "

Dan semua partisipan pada penelitian ini ketika mengungkapkan respon psikologis yang mereka rasakan ketika mengunakan APD adalah partisipan menjawab susah bernafas,

“...Mengunakan APD Panas ee pengap, susah nafas juga”. "Ee maskernya kan double-double tuh"..

"...Kalau yang saya rasakan itu yang pertama pengap susah bernafas”

“...kadang kalau kita kelamaan itu bisa sesak juga pak kita kan double masker gitu” 
Berdasarkan teori adaptasi Roy, Respon psikosomatik saat merawat ODGJ dengan COVID-19dapat dimasukkan ke dalam mekanisme kontrol sistem regulator dan kognator. Hal ini dikarenakan dengan kita harus berpikir positif maka akan merangsang tubuh untuk rileks dan lebih tenang sehingga gejala psikosomatis yang di rasakan perawat tidak ada lagi dan dengan berpikir positif, rasa cemas juga akan berkurang, stres akan menghilang serta meningkatkan daya tahan tubuh. berpikir positif merupakan proses adaptasi yang sangat baik dilakukan oleh perawat dalam upaya mekanisme koping terhadap kecemasan dan mengurangi gejala psikosomatis perawat, ketakutan dan stres terhadap ancaman resiko penularan virus COVID-19. Makin banyak pikiran positif dalam diri perawat, makin terhindar dari tekanan yang dapat mengganggu kondisi psikologis perawat. Jika perawat dapat melaksanakan berpikir positif maka perawat akan menjadi lebih percaya diri dalam memberikan pelayanan yang baik kepada pasien dengan COVID-19.

3. Respon psikologis saat merawat ODGJ dengan COVID-19.

Pandemi COVID-19 merupakan fenomena unik dan belum pernah dialami sebelumnya bagi petugas kesehatan khususnya perawat jiwa dalam merawat ODGJ dengan COVID-19 sehingga respon psikologis saat merawat pasien akan sangat dirasakan oleh perawat dan hal ini tentunya membuat petugas kesehatan mendapatkan stres secara psikologis. Seperti yang dikatakan WHO tahun 2020 bahwa beberapa pengalaman mungkin tidak akan dialami bagi petugas kesehatan yang tidak langsung terlibat dalam kondisi penanganan masalah COVID-19.

Seluruh petugas kesehatan dibandingkan dengan petugas kesehatan yang menghadapi tekanan yang luar biasa akibat COVID-19, terutama yang berhubungan dengan dugaan atau kasus yang dikonfirmasi, karena risiko infeksi yang tinggi, perlindungan yang tidak memadai, kurangnya pengalaman dalam mengendalikan dan mengeloa penyakit, waktu kerja yang lebih panjang, adanya umpan balik negative dari pasien, stigma yang muncul, dan kurangnya dukungan sosial dari lingkungan sekitar.

Menurut (Handayani, Hadi, Isbaniah, Burhan, \& Agustin, 2020), mengatakan bahwa respon kondisi psikologis yang dirasakan tenaga kesehatan selama pandemi COVID-19 seperti stres akibat beban pekerjaan, stigma dapat menularkan virus dan kekhawatiran terinfeksi belum menjadi fokus utama pemerintah di berbagai negara Ini sesuai dengan hasil penelitian ini dimana beberapa partisipan mengatakan

“...kalau saya ngerasa saya di jauhin aja kaya jaga jarak dan gak mau berkumpul "

“...adalah kalau saya ngerasa saya di jauhin aja kaya jaga jarak dan mereka gak mau satu bis ama kita"

“...kalau saya ngerasa saya di jauhin aja kaya jaga jarak dan mereka gak mau satu bis ama kita kan pak jadi dipisah”

Hasil penelitian yang dilakukan oleh (Borer et al., 2012) menunjukkan perawat yang merawat pasien COVID-19 mengalami adanya stres akibat dari ketakutan berada diruang perawatan dengan tekanan negatif dan merasakan kecemasan akan 
menularkan virus tersebut keanggota keluarga atau dilingkungan sekitarnya, Ini sesuai dengan hasil penelitian ini dimana beberapa partisipan mengatakan

“...ketika saya sudah selesai tindakan saya merasa takut apakah saya tidak tertular dan baik baik saja ketika pulang kerumah ”,

“...Respon pertama takut tertular ya ketika kita habis melakukan tindakan kita melepas APD kan dan segera mandi nah ketakutan itu muncul pada saat bersih bersih seperti mandi dan banyak hal nya pak

“...saya merasa belum siap dan takut dalam arti takut menularkan dan takut terjadi sesuatu dari diri saya apakah saya kan baik baik saja”

Selain itu, penelitian yang dilakukan oleh (Mengyuan Li RN et al., 2020) menunjukkan bahwa stres yang terjadi pada petugas garda depan karena terkait masalah pada keamanan pribadi selama bekerja dan tidak siap saat di tugaskan sebagai perawat COVID-19 dan khawatir akan menularkan virus keanggota keluarga juga lingkungan social. Ini sesuai dengan hasil penelitian ini dimana beberapa partisipan mengatakan

“...Respon saya takut tertular karena pasiennya gelisah tidak koperatif sehinga saya takut tertular dan menulari keluarga”

"...Yang saya rasakan takut tertular karena takut di serang pasien dan takut menularkan ke keluarga di rumah”

Beberapa partisipan pada penelitian ini juga mengatakan mereka respon pertama mereka tidak siap dengan penugasan sebagai perawat COVID-19.

“...Kalau di Tanya perasaan pertama di tempatkan di ruangan covid saya mengatakan masih ragu- ragu ya ada rasa siap dan ada rasa tidak siap tapi memang udah suatu perkerjaan jadi saya siap aja”

“...Respon saya pertama bingung dan takut apakah saya bisa merawat pasien odgj dengan covid ada perasaan belum siap juga ada perasaan takut campur aduk lah

Berdasarkan uraian diatas dihubungkan dengan kerangka teori adaptasi Roy dikaitkan dengan Respon psikologis saat merawat ODGJ dengan COVID-19 yaitu tingkat stres lebih tinggi yang dirasakan oleh perawat merupakan dampak psikologis yang muncul dari stimulus kontekstual dan residual, yaitu partisipan belum mempunyai pengalaman yang baik dalam tatalaksana perawatan pasien dengan COVID-19, kecemasan dan ketakutan akan tertular dan menularkan virus COVID-19 sehingga merasa dipisah dengan nakes lain dan juga gangguan rasa nyaman yang timbul dari melakukan pekerjaan dengan prosedur yang belum pernah dilakukan sebelumnya yaitu merawat pasien COVID-19.

4. Tingkat stres saat merawat ODGJ dengan COVID-19.

Merawat pasien dengan COVID-19 membuat perawat merasa tidak nyaman saat situasi pandemi karena mengalami stress saat melakukan tindakan keperawatan. Kegiatan perawatan yang dilakukan pada pasien COVID-19 menimbulkan ketidaknyaman perawat jiwa saat merawat pasien covid sehingga berdampak respon psikologis bagi perawat dan tingkat stress yang mereka alami berbeda beda tiap 
individu dan Perawat juga sebagai petugas kesehatan garda depan dalam menjalankan tugasnya juga mengalami adanya perasaan frustasi karena harus bekerja diruang isolasi, khawatir akan terinfeksi, kekurangan alat perlindungan diri selama bekerja, pandemik yang tidak akan pernah bisa dikendalikan, hasil pekerjaan yang tidak memuaskan dalam merawat pasaien COVID-19, dan merasa kesepian karena diisolasi dari anggota keluarga dan lingkungan tempat tinggal hal tersebut mengakibatkan dampak berupa stress fisik, stress psikologi dan juga stress social yang merupakan dampak saat merawat pasien ODGJ dengan COVID-19.

Menurut penelitian Rini Tazkirah 2021 menunjukkan bahwa perawat merasakan stres ringan (36,5\%) selama merawat pasien COVID-19. Hal ini sejalan dengan penelitian yang telah dilakukan oleh Saleha et al (2020) bahwa perawat yang merawat pasien COVID-19 mengalami stres ringan (51,8\%). Hal ini dapat disebabkan karena $82,5 \%$ perawat sudah mengikuti workshop penggunaan APD/manajemen perawatan pasien COVID-19 dan pandemi telah berlangsung lebih dari satu tahun sehingga dapat menimbulkan stress fisik, stress psikologis dan juga stress social di masyarakat. Ini sesuai dengan hasil penelitian ini dimana beberapa partisipan

“...Kalau perasaan pertama merawat pasien covid Pertama kali itu agak waswas juga”

“...Jadi awal itu memang belum dapat informasi jadi ada ketakutan setelah kita baca baca dan beberapa lama sudah merawat pasien covid jadi sudah biasa aja pak sudah agak santai aja”

"...Jadi awal itu memang belum dapat informasi jadi ada ketakutan kemudian setelah kita abaca baca dan beberapa lama sudah merawat pasien covid jadi sudah biasa aja pak"

Hasil penelitian ini juga didukung oleh penelitian (Li et al., 2020) bahwa kurang dari $60 \%$ tenaga kesehatan yang didominasi oleh perawat merasakan stres sedang atau berat, sehingga perawat merasakan stres ringan meskipun masih adanya rasa takut tertular dan merasa tidak nyaman ketika menggunakan alat pelindung diri Ini sesuai dengan hasil penelitian ini dimana beberapa partisipan mengatakan

"...Stressnya ringan sih"..."Menentukan Tingkat ringan karena ya itu udah pekerjaan aja sih"

“...Jadi tingkat stress Sedang Karna disisi lain sudah kita tau Penanganannya”

“...kalau waktu pertama kali itu ee bisanya stress sedang kayaknya”

Beberapa partisipan pada penelitian ini juga mengatakan mengalami stress social yaitu mereka hanya menegur dari kejauhan dan tidak berkumpul kumpul saat dilingkungan rumah dengan ungkapan partisipan

“...Pertama dulu keliatan menjauh jaga jarak membuat saya terganggu juga tapi tidak begitu Nampak."

“...respon mereka seperti tidak mau bicara dan menjaga jarak saja itu saat pertama kali tau tapi setelah beberapa lama jadi hal yang biasa saja 
Berdasarkan data yang dapat berhubungan dengan teori adaptasi Roy, Tingkat stres saat merawat ODGJ dengan COVID-19 dapat menjadi stimulus fokal yang selanjutnya dikontrol oleh system regulator dan kognator. Perawat mempunyai tantangan untuk beradaptasi melawan stress rasa cemas dalam melakukan kontak saat berinteraksi dengan pasien ODGJ dengan COVID-19. Bentuk adaptasi yang dilakukan perawat adalah kontak seminimal mungkin dengan pasien tetapi tetap berusaha semaksimal mungkin dalam melakukan tindakan keperawatan sesuai kebutuhan pasien sehingga tingkat stress yang di alami perawat tidak menganggu dalam proses perawatan pasien ODGJ.

5. Cara mengelola stres saat merawat pasien ODGJ dengan COVID-19.

Merawat pasien dengan COVID-19membuat perawat merasa tidak nyaman saat situasi pandemi karena mengalami stress saat melakukan tindakan keperawatan sehingga perawat harus bisa mengeloa stress saat pandemi COVID-19 ini Krisis psikologis pada tenaga kesehatan juga yang diakibatkan pandemi COVID-19 diperkirakan akan memicu kebutuhan mendesak untuk merancang dan mengimplementasikan dukungan psikososial dan intervensi program untuk mengurangi tekanan psikologis dan Petugas kesehatan sangat beresiko tinggi mengalami masalah kejiwaan berupa stres ringan hingga berat karena berbagai tekanan yang meningkat dan harus mereka hadapi saat merawat pasien dikala pandemi covid yang tidak dapat kita prediksi sampai sampai kapan berakhir sehingga di haruskan para petugas kesehatan khususnya perawat mampu mengelola stress dimasa pandemi covid dengan berdoa, istirahat yang cukup, olahraga dan kebutuhan Vitamin sehingga respon psikologis perawat tidak cemas saat pendemic COVID-19.

Menurut penelitian Timmins 2017 menjelaskan bahwa cara mengelola stress saat merawat pasien adalah dengan penguatan kebutuhan spiritual dengan cara berdoa yang terpenuhi ini sangat efektif dapat meningkatkan koping perawat saat menghadapi situasi yang sulit atau menantang. Pada kondisi pandemi ini kehidupan spiritual akan menjadi bagian yang sangat penting dari koping. Kehidupan spiritual yang baik akan membangun koping yang kuat secara spiritual dalam menghadapi masa sulit di tengah pandemi COVID-19 ini Ini sesuai dengan hasil penelitian ini dimana beberapa partisipan mengatakan

“...banyak - banyak berdoa banyak - minta perlindung pada allah SWT terus ya harus yakin jangan ragu dalam melakukan pelayanan untuk membantu orang lain karena sudah tugas kita sebagai perawat"

“...saya untuk mengatasi stress nya biasa sih ee berdoa misalkan minta perlindungan dengan Tuhan"

“...yang pertama itu saya selalu berdoa agar di berikan kelancaran dan kesahatan dalam merawat"

Hal ini sejalan juga dengan penelitian mayuri 2017 menjelaskan bahwa cara mengelola stress saat merawat pasien adalah dengan Pentingnya istirahat dan tidur merupakan suatu kebutuhan sebagai bentuk perlindungan dari organisme untuk menghindari pengaruh yang merugikan tubuh karena kurang tidur dan sangat efektif 
dalam mengelola stress selama merawat pasien Ini sesuai dengan hasil penelitian ini dimana beberapa partisipan mengatakan

"...Kalau tidur kita cukup , misalnya pikiran juga lebih enak Itu sih tidur yang utama”

“...istirahat yang cukup agar kondisi tubuh sehat lagi”

“...pulang dinas saya selalu istirahat yang cukup dan tidak begadang”

Beberapa partisipan pada penelitian ini juga mengatakan cara mengelola stress saat merawat pasien ODGJ dengan COVID-19 yaitu mereka selalu membaca SPO dan panduan ruangan covid.

“...setelah itu saya baca buku panduan ruangan dan SOP ruangan memperdalam ilmu tentang covid saya

“...Membaca SOP di ruangan dan membaca buku dan informasi tentang covid”

“...yang terpenting adalah pemahaman kita tentang COVID-19 selebihnya perdalam pengetahuan dan membaca SPO dan panduan ruangan “

Berdasarkan teori adaptasi Roy, mengelola stress saat merawat pasien ODGJ dengan COVID-19 termasuk dalam mekanisme kontrol sistem regulator dan kognator. Hal ini dikarenakan jika perawat mampu mengelola stress dengan baik maka dapat merangsang tubuh menjadi rileks dan lebih tenang dan juga dengan mengelola stress dengan berpikir positif, rasa cemas juga akan berkurang, stres akan menghilang serta meningkatkan daya tahan tubuh. Jika perawat dapat mengelola stress saat merawat pasien maka perawat akan menjadi lebih percaya diri dalam memberikan pelayanan yang baik kepada pasien dengan COVID-19.

6. Keberhasilan mengelola diri mengatasi stress saat merawat pasien ODGJ dengan COVID-19.

Kesiapan baik fisik maupun psikologis mutlak diperlukan perawat dalam menjalankan tugasnya dalam melakukan koping dalam mengelola stress. Seringkali perawat menghadapi situasi yang tidak menyenangkan (risk situation) di tempat kerjanya dengan perilaku pasien yang mampu membuat perawat kehilangan konsentrasi. Perilaku kekerasan yang dilakukan pasien dapat berakibat fatal baik bagi perawat. Bila situasi yang menekan ini tidak segera diatasi, tidak menutup kemungkinan akan menimbulkan stres dan konflik pada diri perawat. Berbagai cara yang dilakukan oleh perawat untuk mengatasi agresivitas pasien yang diarahkan padanya akan menimbulkan berbagai dampak negatif baik pada diri perawat.

Masing-masing individu memiliki strategi mengatasi stres yang berbeda-beda. Ada yang menghindari sumber stres untuk mengatasi rasa tertekan, ada pula yang mencari cara untuk menyelesaikan masalah yang menyebabkan stres. Strategi yang digunakan oleh individu dalam mengatasi stres inilah yang disebut coping stres yaitu suatu proses pemulihan kembali dari pengaruh pengalaman stres atau reaksi fisik dan psikis yang berupa perasaan tidak enak, tidak nyaman atau tertekan yang sedang dihadapi individu yang meliputi strategi kognitif dan perilaku yang digunakan untuk mengelola situasi penuh stres dan emosi negatif yang tidak menguntungkan. 
Menurut Stuart \& Sundeen dalam Yuanita,2015 Mekanisme koping adalah cara yang digunakan individu dalam menyelesaikan masalah, mengatasi perubahan yang terjadi, dan situasi yang mengancam, baik secara kognitif maupun perilaku. Mekanisme koping yang digunakan bertujuan agar perawat mampu beradaptasi dan menjalani tugas dengan baik dan tetap dalam kondisi kesehatan yang optimal sehingga respon Tubuh yang di alami setiap perawat menjadi rileks, tidak cemas, percaya diri meningkat Ini sesuai dengan hasil penelitian ini dimana beberapa partisipan mengatakan Ini sesuai dengan hasil penelitian ini dimana beberapa partisipan mengatakan

"...yang saya rasakan adalah kalau saya beristirahat saya menjadi segar dan tubuh saya rileks ada rasa nyaman saja"

"... respon tubuh saya menjadi agak enakan dan rileks karena istirahat yang cukup itu mengumpulkan tenanga kita dan kita kalau rileks karena sudah istirahat"

“...respon tubuh yang saya rasakan ketika saya beristirahat dengan cukup yaitu tubuh terasa enak dan rileks karena kita sangat memerlukan istirahat yang cukup apalagi virus covid menyerang kalau badan kita lemah"

Sejalan dengan penelitian Dengan In The Know:2014 memahami teori dan konsep stress, seseorang dapat memiliki kuasa penuh dalam mengontrol diri dan emosinya sehingga ia dapat mengoptimalkan kemampuan dan kekuatan yang dimilikinya untuk mengatasi stress yang di alami dan dapat memenajamen stress dengan baik agar percaya diri lebih meningkat Ini sesuai dengan hasil penelitian dimana beberapa partisipan

"...respon fisik saya ketika saya sudah tau informasi saya tidak lagi cemas saat masuk ke ruangan covid dalam memberikan asuhan santai aja sudah"

"...kalau pemahaman pedoman dan SPO kita tidak cemas dengan penanganan dan tata kelola di lapangan jadi gak buta dalam segala sesuatu”

"...dengan mengumpulkan informasi dan pemahaman SPO dan panduan saya tidak cemas dengan hal yang boleh saya lakukan dan tidak boleh saya lakukan"

Hal tersebut sejalan dan diperkuat dengan peneltian Talita, (2015) bahwa keyakinan dan spritual juga dapat di gunakan sebagai mekanisme koping berhubungan dengan peningkatan kesehatan fisik dan mental seseorang, positif yang muncul yaitu: meningkatkan fungsi kekebalan; kebahagiaan, tingkat kepuasan hidup yang lebih tinggi; harapan yang lebih baik; sifat optimis; dan penurunan tingkat kecemasan dan depresi tidak cemas tubuh menjadi rileks dan percaya diri dalam segala hal dimana beberapa partisipan mengatakan

“...respon tubuh saya juga menjadi tidak cemas karena banyak cara dan aturan terkait penanganan pasien COVID-19yang terbaru itu sangat membantu juga"

“...yakin diri saja karena sudah paham alur dan spo jadi sugesti ke kita juga kita jadi tidak cemas dan takut"”

Beberapa partisipan pada penelitian ini juga mengatakan respon tubuh mereka menjadi lebih rilkes, tidak cemas lagi percaya diri meningkat saat melakukan manajemen stress dengan berdoa dan di rasa lebih efektif untuk mengurangi stress 
dan mengurangi gejala psikosomatik saat merawat pasien ODGJ dengan COVID-19 dengan partisipan mengatakan

"...yang saya rasakan adalah saya menjadi lebih percaya diri kalau saya mendahulukan perkerjaan saya dengan berdoa dan meminta pertolongan kepada Tuhan"

“...dengan berdoa kita lebih yakin dan percaya diri kalau pada saat kita melakukan tindakan kita pasti di lindungi oleh Tuhan kaya tenang aja sieh

“...respon fisik saya dengan berdoa saya percaya kalau saya akan selalu di lindungi oleh sang pencipta kita dan selalu di tuntun pada setiap langkah dalam perkerjaan kita"

Koping dalam mengelola stress oleh perawat yang bertugas dalam merawat pasien ODGJ dengan COVID-19 menurut teori adaptasi Roy menjadi stimulus kontekstual yang dapat memicu adanya mekanisme kontrol sistem regulator dan kognator untuk mengatasinya. Kecemasan akan dapat berkurang atau bahkan hilang jika perawat mampu beradaptasi dengan baik dan mengelola stress dengan benar dan tepat sehingga respon tubuh menjadi rileks dan tidak cemas lagi.

\section{Kesimpulan}

Hasil penelitian ini menjelaskan tentang para partisipan dalam studi ini memiliki pengalaman perawat jiwa untuk melakukan self manajemen diri dalam mengelola stress pada masa pandemi COVID-19 dan pengalaman ini merupakan hasil dari penggalian informasi yang dilakukan peneliti melalui metode wawancara dan observasi yang ada dilokasi penalitian berdasarkan hasil peneilitian Tema tersebut adalah (1) Prilaku pasien ODGJ saat di rawat ; (2) Respon fisik perawat saat merawat Pasien ODGJ dengan COVID-19; (3) Respon psikologis saat merawat ODGJ dengan COVID-19; (4) Tingkat stres saat merawat ODGJ dengan COVID-19; (5) Cara mengelola Stres saat merawat pasien odgj dengan COVID-19; (6) Keberhasilan mengelola diri mengatasi stress saat merawat pasien ODGJ dengan COVID- hasil hasil temuan temuan ini dapat di impelementasikan dalam pelayanan keperawatan untuk adaptasi dalam mengelola stress dengan melakukan manajemen diri ketika memberikan asuhan kepada pasien. ODGJ dengan COVID-19

Simpulan dari penelitian ini bahwa perawat perlu suatu adaptasi dalam mengelola stress dengan melakukan manajemen diri ketika memberikan asuhan kepada pasien. 


\section{BIBLIOGRAFI}

Borer, Abraham, Saidel-Odes, Lisa, Eskira, Seada, Nativ, Ronit, Riesenberg, Klaris, Livshiz-Riven, Ilana, Schlaeffer, Francisc, Sherf, Michael, \& Peled, Nejama. (2012). Risk factors for developing clinical infection with carbapenem-resistant Klebsiella pneumoniae in hospital patients initially only colonized with carbapenem-resistant K pneumoniae. American Journal of Infection Control, 40(5), 421-425.Google Scholar

Damaiyanti dan Iskandar. (2014). Asuhan Keperawatan Jiwa. Bandung: Refika Aditama.

Dong, Zai Quan, Ma, Jing, Hao, Yan Ni, Shen, Xiao Ling, Liu, Fang, Gao, Yuan, \& Zhang, Lan. (2020). The social psychological impact of the COVID-19 pandemic on medical staff in China: A cross-sectional study. European Psychiatry, 63(1). Google Scholar

Economou, Marina, Angelopoulos, Elias, Peppou, Lily Evangelia, Souliotis, Kyriakos, Tzavara, Chara, Kontoangelos, Konstantinos, Madianos, Michael, \& Stefanis, Costas. (2016). Enduring financial crisis in Greece: prevalence and correlates of major depression and suicidality. Social Psychiatry and Psychiatric Epidemiology, 51(7), 1015-1024. Google Scholar

Elita, Veny. (2011). Persepsi perawat tentang perilaku kekerasan yang dilakukan pasien di ruang rawat inap jiwa. Jurnal Ners Indonesia, 1(2), 31-40. Google Scholar

Febriana, Nina Indah. (2016). Analisis Kualitas Pelayanan Bank Terhadap Kepuasan Nasabah Pada Bank Muamalat Indonesia Kantor Cabang Pembantu Tulungagung. IAIN Tulungagung Research Collections, 3(1), 145-168. Google Scholar

Frith, Uta, \& Frith, Chris. (2001). The biological basis of social interaction. Current Directions in Psychological Science, 10(5), 151-155. Google Scholar

Hales, Craig M., Carroll, Margaret D., Fryar, Cheryl D., \& Ogden, Cynthia L. (2017). Prevalence of obesity among adults and youth: United States, 2015-2016. Google Scholar

Handayani, Diah, Hadi, Dwi Rendra, Isbaniah, Fathiyah, Burhan, Erlina, \& Agustin, Heidy. (2020). Corona virus disease 2019. Jurnal Respirologi Indonesia, 40(2), 119-129. Google Scholar

Husada, Stikes Kusuma. (N.D.). Hubungan Perilaku Agresif Pasien Dengan Stres Perawat Di Psikiatri Intensive Care Unit (Picu) Rsjd Surakarta. Google Scholar

Keliat. (2011). Terapi Aktivitas Kelompok. Repository USU, 126. 
Kruk, Joanna, Aboul-Enein, Basil Hassan, Bernstein, Joshua, \& Gronostaj, Magdalena. (2019). Psychological stress and cellular aging in cancer: a meta-analysis. Oxidative Medicine and Cellular Longevity, 2019. Google Scholar

Li, Peng, Fu, Ji Bo, Li, Ke Feng, Liu, Jie Nan, Wang, Hong Ling, Liu, Lei Jie, Chen, Yan, Zhang, Yong Li, Liu, She Lan, \& Tang, An. (2020). Transmission of COVID-19 in the terminal stages of the incubation period: a familial cluster. International Journal of Infectious Diseases, 96, 452-453. Google Scholar

McAlonan, Grainne M., Lee, Antoinette M., Cheung, Vinci, Cheung, Charlton, Tsang, Kenneth W. T., Sham, Pak C., Chua, Siew E., \& Wong, Josephine G. W. S. (2007). Immediate and sustained psychological impact of an emerging infectious disease outbreak on health care workers. The Canadian Journal of Psychiatry, 52(4), 241247. Google Scholar

Mengyuan Li RN, B. S. N., Qian Shi RN, B. S. N., Ling Yan, R. N., Li Tian RN, B. S. N., Haozheng Li RN, B. S. N., Junshuai Lu RN, B. S. N., \& Shuqing Xiao RN, B. S. N. (2020). A qualitative systematic review of the experiences and needs of patients with gliomas. Oncology Nursing Forum, 47(5), E120-E130. Oncology Nursing Society. Google Scholar

Prabowo, Eko. (2014). Konsep \& aplikasi asuhan keperawatan jiwa. Google Scholar

Sharma, Atul, Tiwari, Swapnil, Deb, Manas Kanti, \& Marty, Jean Louis. (2020). Severe acute respiratory syndrome coronavirus-2 (SARS-CoV-2): a global pandemic and treatment strategies. International Journal of Antimicrobial Agents, 56(2), 106054. Google Scholar

Sockalingam, Sanjeev, Clarkin, Chantalle, Serhal, Eva, Pereira, Cheryl, \& Crawford, Allison. (2020). Responding to health care professionals' mental health needs during COVID-19 through the rapid implementation of Project ECHO. Journal of Continuing Education in the Health Professions, 40(3), 211-214. Google Scholar

Stuart, G. W., \& Laraia, M. T. (2008). Principles And Practice Of Psychiatric Nursing Eight edition St. Louis. Missouri: Mosby Inc. Google Scholar

Vickers, Neil J. (2017). Animal communication: when i'm calling you, will you answer too? Current Biology, 27(14), R713-R715. Google Scholar

Yaribeygi, Habib, Panahi, Yunes, Sahraei, Hedayat, Johnston, Thomas P., \& Sahebkar, Amirhossein. (2017). The impact of stress on body function: A review. EXCLI Journal, 16, 1057. Google Scholar

Yuan, Shuai, Liao, Zhenxin, Huang, Haojie, Jiang, Boyue, Zhang, Xueyan, Wang, Yingwen, \& Zhao, Mingyi. (2020). Comparison of the indicators of psychological stress in the population of Hubei province and non-endemic provinces in China during two weeks during the coronavirus disease 2019 (COVID-19) outbreak in February 2020. Medical Science Monitor: International Medical Journal of 
Pengalaman Perawat Jiwa Melakukan Self Manajemen Diri dalam Mengelola Stres Dimasa Pandemi Covid-19

Experimental and Clinical Research, 26, e923767-1. Google Scholar

Zeng, Fanmin, Sun, Xueli, Yang, Bangxiang, Shen, Hong, \& Liu, Ling. (2016). The theoretical construction of a classification of clinical somatic symptoms in psychosomatic medicine theory. PloS One, 11(8), e0161222. Google Scholar

\section{Copyright holder:}

Maradona, Yati Afiyanti, Muhammad Syafwani (2021)

First publication right:

Syntax Idea

This article is licensed under:

(c) (i) (O) 